\title{
RISK FACTORS FOR INFANT DEVELOPMENTAL PROBLEMS ${ }^{1}$
}

\author{
Margaret Rose Santa Maria-Mengel ${ }^{2}$
}

Maria Beatriz Martins Linhares ${ }^{3}$

Maria-Mengel MRS, Linhares MBM. Risk factors for infant developmental problems. Rev Latino-am Enfermagem 2007 setembro-outubro; 15(número especial):837-42.

This descriptive-correlational study aimed to detect risks for child developmental problems in the first four years of age, to identify the protective resources in the familiar environment, and to verify the best predictive variables of the development at risk. The non-clinical sample was composed by 120 children registered in a Family Health Program. The assessment instruments for global development, expressive language and familiar environment were used. The logistic regression analysis indicated that the lower the father's educational level, the higher the risk for developmental problems. Both the history of low nutritional state at six months of age and the psychosocial risk in the family environment increased the chances of having expressive language problems. It is concluded that screening tests of risk for developmental problems and the analysis of the psychosocial factors in the familiar context should be considered as preventive intervention procedure in the Family Health Programs.

DESCRIPTORS: child development; risk; triage; family health program

\section{FACTORES DE RIESGO PARA PROBLEMAS DE DESARROLLO INFANTIL}

El estudio descriptivo-correlacional objetiva detectar riesgos para problemas del desarrollo del niño en los cuatro primeros años, identificar recursos protectores en el ambiente familiar, verificar las mejores variables antedichas del desarrollo en riesgo, en una muestra no-clínica de 120 niños registrados en un Programa de Salud de la Familia. Fueron utilizados instrumentos de evaluación del desarrollo global, lenguaje expresivo del niño y ambiente familiar. El análisis de regresión logística indicó que cuanto menor escolaridad del padre, mayor chance de riesgo para problemas de desarrollo. El histórico del estado nutricional debajo de lo normal a los seis meses de edad y el riesgo psicosocial en el ambiente familiar aumentaba la probabilidad de problemas de lenguaje expresivo. Concluyendo, la selección de riesgos para problemas de desarrollo del niño y el análisis de factores psicosociales del contexto familiar deben incluirse como procedimientos de intervención preventiva en programas de Salud de la Familia.

DESCRIPTORES: desarrollo infantil; riesgo; triage; programa salud de la familia

\section{FATORES DE RISCO PARA PROBLEMAS DE DESENVOLVIMENTO INFANTIL}

Este estudo descritivo-correlacional teve por objetivo detectar riscos para problemas do desenvolvimento da criança nos quatro primeiros anos, identificar recursos protetores no ambiente familiar e verificar as melhores variáveis preditoras do desenvolvimento em risco, em amostra não-clínica composta por 120 crianças cadastradas em um Programa de Saúde da Família. Utilizaram-se instrumentos de avaliação do desenvolvimento global, da linguagem expressiva da criança e do ambiente familiar. A análise de regressão logística indicou que quanto menor a escolaridade do pai, maior a chance de risco para problemas de desenvolvimento. A história do estado nutricional abaixo do normal aos seis meses de idade e o risco psicossocial no ambiente familiar aumentava a probabilidade de problemas de linguagem expressiva. Conclui-se que a triagem de riscos para problemas de desenvolvimento da criança e a análise dos fatores psicossociais do contexto familiar devem ser incluídas como procedimento de intervenção preventiva em Programas de Saúde da Família.

DESCRITORES: desenvolvimento infantil; risco; triagem; programa saúde da família

${ }^{1}$ Financial support provided by Foundation of Support to Teaching, Research and Assistance from the HCFMRP-USP; ${ }^{2}$ Doctoral Student, e-mail: mrsm2@uol.com.br; ${ }^{3}$ PhD Professor, e-mail: linhares@fmrp.usp.br. University of São Paulo at Ribeirão Preto, Medical School, Brazil 


\section{INTRODUCTION}

The first three years of life have been prioritized because it is a development stage characterized by important acquisitions and by cerebral plasticity ${ }^{(1)}$. In this phase, great advancements occur in the motor, cognitive and social area(2), as well as the acquisition and control of language ${ }^{(3)}$, which are essential for the child's global development and learning.

A search for quality of life has been observed in Family Health Programs inserted in the community, seeking a good adaptation during the development process. In this sense, the risk focus has been used for the recognition and early follow-up of some groups that are more vulnerable to morbidities. This action is important for care delivery according to the person's level of risk, considering risk as "the greatest probability an individual or group of people has of suffering any damage to their health in the future" ${ }^{\prime(4)}$.

The effective identification of children at risk, using a comprehensive approach, starts with an examination of risk factors that contribute to children's disorders, making them vulnerable to cope with the developmental tasks of the life cycle. The risks to development can be present in the children themselves (biological components, temperament and symptoms), in the family (parents' history and family dynamics) or in the environment (socioeconomic level, social support, education and cultural context) ${ }^{(5)}$.

When assessing risk factors to "resilience", it should be taken into account that it are individual differences in people's response to stress and adversity that work as protection mechanisms ${ }^{(6)}$. Thus, the family context can contribute to resilience processes in development courses. Children must be understood in their different development contexts, including the range from the family micro-system to the cultural macro-system they are inserted in ${ }^{(7)}$. The family's psychosocial risk can be evaluated through an index that includes relevant variables present in the child's daily reality, such as: the parents' low education level, frequent marital problems, overloaded houses, rejection of pregnancy, early motherhood/ fatherhood, among others ${ }^{(8)}$.

In the prevention sphere, tracking risks in initial development requires instruments for largescale application by different professionals, in order to detect potential problems in advance. This practice is in accordance with primary child health care objectives. In this sense, instruments under the form of Lists and Inventories, such as the Denver II Development Screening Test ${ }^{(2,9)}$ and the Language Development Survey $(\operatorname{LDS})^{(3,10)}$. In parallel with the evaluation of infant development indicators, risks and resources in the family environment context also need to be assessed, in this case, using the HOME Inventory ${ }^{(11-13)}$.

Experts in child development in primary child health care need to know how a child with a typical development behaves, as well as to identify which factors can contribute to atypical development. The objectives of the present study were: a) to detect risk factors for child development problems in the four first years of life; b) to identify protection resources in the family environment context; c) to identify the best variables to predict these risks.

\section{METHOD}

The sample consisted of 120 male and female children, between 6 and 44 months old, from a nonclinical sample of a community attended in Family Health Nucleus IV, affiliated with the University of São Paulo at Ribeirão Preto Medical School. At the time of data collection, the population registered at this Nucleus was composed of 311 children, 76 of whom were newborns under 12 months of age and 235 were children between 12 and 48 months old. The initial potential sample was composed of 199 children; however, $79(40 \%)$ did not participate in the study due to the following reasons: refused to participate $(16 \%)$, moved outside the area covered by the Nucleus (18\%) and impossibility to participate due to the mother's work hours $(6 \%)$.

The families' registration files from the community agents and the files of children attended at Nucleus IV were consulted in order to identify those who met the age criterion. After the children's identification, the family was contacted and invited to participate in the study. The families signed a free and informed consent term and participated in a feedback interview on the results of the evaluation, received orientation and were referred to experts when necessary. This study was approved by the Academic Directory of Teaching and Research at the Teaching Health Center at Ribeirão Preto Medical School - FMRP - USP and by the same Center's Research Ethics Committee. 
The evaluation of the child and family environment was previously scheduled and performed during one single home visit. The children were individually assessed through the Denver II Test, which indicates development risk or normality, identifying delay or care indicators. The mothers answered the Interview Guide for Biopsychosocial Risk ${ }^{(14)}$, the Psychosocial Risk Index ${ }^{(8)}$, the $\operatorname{LDS}^{(10)}$ ) (only for children from 24 to 44 months), the Vital Events Scale ${ }^{(15)}$ and the ABIPEME (Brazilian Association of Market Research Institutes) questionnaire ${ }^{(16)}$. The Home Observation for Measurement of the Environment ${ }^{(13)}$ was filled out through the researcher's observation of the child's home during the home visit.

In addition to the descriptive statistical analysis of the sociodemographic characteristics and the variables studied in terms of the results obtained through the assessment instruments, a logistic regression analysis was also performed. The Statistical Package for Social Sciences for Windows (SPSS) version 12.0 was used for data analysis and a $5 \%$ significance level was adopted $(=0.05)$.

\section{RESULTS}

The sample was composed of 120 children from 6 to 44 months old (median=22 months), 58\% male, including $27 \%$ of children who attended day care. The children belonged to 107 families because, in some of the families, there was more than one child that met the study criteria. Regarding the families' characteristics, they were predominantly formed $(98 \%)$ by biological parents who were the children's caregivers. Regarding the parents' marital status, stable unions (77\%) prevailed, while $18 \%$ were single mothers. The parents were young adults, median age between 25 and 29 years old, ranging from 14 to 49 and 20 to 58 years old, respectively. If the caregivers were the grandparents, they were elderly, with a median age between 70 and 72 , varying between 68-70/72-78 respectively. The caregivers' prevailing education level was four years, which corresponds to primary education. Regarding professional occupation, $53 \%$ of the female caregivers had no remunerated activity and stayed at home, while $24 \%$ were unemployed. Most male caregivers $(66 \%)$ performed a non-qualified or semiqualified occupational activity and $10 \%$ were unemployed.
Regarding socioeconomic status, a little more than half (54\%) of them came from level-D families, while the remainder predominantly belonged to level C $(22 \%)$ and $E(17 \%)$, according to the ABIPEME classification. In most families (71\%), the father was considered the breadwinner. The family income varied from a declared absence of income up to $R \$ 2,300.00$, while the median was $R \$ 500.00$. Regarding the place of residence, a large majority of the children (68\%) lived in a slum.

According to the Denver II test, $33 \%$ of the total of 120 children presented risk for development problems. The risk was more due to the presence of "care" indicators than to actual "delays" in global development. In the specific areas of language, fine and gross motor skills, items considered with "care" were present in $35 \%, 19 \%$ and $21 \%$, respectively. It should be appointed that, in the expressive and respective language area, a high number of children presented "special care" indicators (35\%), while 4\% presented "delay.

Regarding LDS results, for the 56 children evaluated between 24 and 44 months old, a median standard score of 90.95 was found. There was a predominance of normal classification (93\%), with a small risk percentage (7\%) for problems of specific development of expressive language, which involved the evaluation of vocabulary in the children's speech repertory.

Considering the HOME inventory, the median score of 30 in a set of 45 items was verified. In addition, $74 \%$ of the children presented a medium level of stimulation in the family environment. High scores were found for the subscales of responsiveness, acceptance of the child, organization of the physical environment in general, maternal involvement with the child and opportunities to vary daily stimuli, except for the provision of material appropriate for the child's age. It can be highlighted that, in this subscale, as well as in the acceptance of the child and in maternal involvement, the inferior limit of the variation range was zero; which means that, in some families, there were no toys available to the child, little acceptance of the child and little involvement by the mothers.

Regarding potentially stressing vital events the families experienced in the last year, reported by the mothers in the Vital Events Scale, the median was six events, ranging from zero to 15 . The highest occurrence of adverse events was in the areas related 
to family matters (76\%) and personal difficulties $(75 \%)$, financial areas $(66 \%)$, work $(62 \%)$, changes in the environment (52\%) and loss of social support $(44 \%)$. The higher incidence of adverse events in the sample, with rates over $25 \%$, were related to debts (54\%) and financial losses (44\%), followed by a birth in the family $(45 \%)$, unemployment (43\%), changes in recreational activities ( $41 \%)$ and change in the number of people living in the house $(40 \%)$.

The prediction model analyzed through logistic regression revealed only the father's education level variable as a predictor of risk for global development problems in children between 6 and 44 months old. Regarding the development of expressive language, two variables were found as the best predictors of the child's vocabulary. Children with a history of nutritional state below normal at the age of six months, according to the caregiver, presented 16 times more chances of presenting language problems. In addition, the presence of high psychosocial risk in the family's environment ${ }^{(8)}$ implied four times more chances of a child having expressive language development problems (Table 1 ).

Table 1 - Logistic regression analysis of risk factors for the child's development

\begin{tabular}{|c|c|c|c|}
\hline Development indicators & P-value & OR & $\mathrm{Cl}(95 \%)$ \\
\hline \multicolumn{4}{|c|}{ Global Development (Denver-II) - 6 to 44 months } \\
\hline Father's education & 0.04 & 0.40 & $0.17-0.97$ \\
\hline \multicolumn{4}{|c|}{ Expressive Language (LDS) - 24 to 44 months } \\
\hline Nutritional State at 6 months & 0.05 & 16.94 & $0.93-308.07$ \\
\hline $\begin{array}{l}\text { Psychosocial Risk Index (sum } \\
\text { of items) }\end{array}$ & 0.05 & 4.07 & $0.96-17.18$ \\
\hline
\end{tabular}

$\mathrm{P}$-value $=0.05 ; \mathrm{OR}=$ Odds Ratio $; \mathrm{CI}=$ Confidence Intervals

\section{DISCUSSION}

The results regarding the children's difficulties and individual resources showed that, in this sample, $33 \%$ of them were at risk of developing problems. More care than delay indicators were present in the acquisition of developmental abilities. These results are similar to the Brazilian study that used the Denver II Test and found $34 \%$ of suspicion of delay in the development of children without risk established at 12 months of corrected chronological age, who had been born at the hospital of Pelotas and lived in the urban area $^{(2)}$.

It should be highlighted that the suspicion level of risk in language, identified through the Denver II
Test, was higher that the one found by the LDS (7\%). The Denver II Test evaluates receptive and expressive language in terms of comprehension and expression, not only by words, but also by sounds imitating the adult or by the baby's pointing movement.

The LDS evaluates expressive language, which is presented by means of words expressed comprehensively to relatives and people non-familiar to the child. The presence of children at risk in this area in the first years of life deserves attention and care, because it is an area of extreme importance for development, as it is directly linked with social communication, cognitive development and school learning ${ }^{(17)}$

Regarding the development context of children in the study sample, it was observed that, in the family environment, there were indications of severe psychosocial risk. The children's caregivers presented low education levels (around four years of study) and semi-qualified or non-qualified professions, belonged to socioeconomic class $\mathrm{D}$ and had a median family income of less than to two current minimum wages. Most mothers did not generate income, because they stayed at home (53\%) or were unemployed (24\%).

The parents' education and employment variables are considered distal variables, according to the ecological theory, in the contexts of the child's development, which in turn can directly influence the social proximal interactions that occur in the family micro-system, thus indirectly affecting his(er) development ${ }^{(7)}$. This configuration of indicators permitted identifying that the children's development contexts contained multiple psychosocial distal risks, involving low education and insufficient family income to provide basic material resources for their support.

Regarding the proximal variables of the family context, good levels of environmental stimulation were found. Therefore, the facts that children are cared for by their biological parents, living in a stable union, and receive positive stimuli at their homes seem to act as protection mechanisms in the context of psychosocial adversity the families live in.

On the other hand, the children's caregivers reported family matters and personal, financial or work difficulties as sources of stress. Literature appoints that the family environment with less resources and higher adversity, including problems in interpersonal relationships, can cause problems for the child's emotional and behavioral development ${ }^{(18)}$. 
The prediction model showed that, the higher the father's education level, the lesser the chance of risk for the child's global development. This result can be in accordance with the hypothesis that the higher the education level, the better the father's job, which promotes income and opportunities of better conditions of adequate stimuli for the child's development. In the same way as the mother's education acts as a protection factor for the child's development, the father's education can also acts as such.

The history of nutritional status below normal at the age of six months, as reported by the caregivers, was a predictor of development problems in expressive language, confirming the results of the study on the influence of breastfeeding on the children's cognitive functions ${ }^{(19)}$.

The presence of psychosocial risk factors in the child's life also functioned as a predictor of expressive language problems ${ }^{(8)}$. It can be considered that, due to the presence of several (emotional and relationship) problems, the caregiver is not available to provide verbal stimuli necessary for the child's vocabulary development. In addition, low education levels and chronic unemployment constitute variables with a strong impact on the child's development.

Despite the distal psychosocial risk present in the sample, its negative effects can be moderated by protection mechanisms of development, provided by proximal variables of the social relationship dynamics and of the stimulation of family relationships, which were positively evaluated through the HOME inventory. The children's first interactions with the social environment, especially with the primary caregivers, are fundamental for their development, because it is a phase in which the mind is rapidly developing, establishing neural connections and creating a context that expands into a network of relationships, causing a strong impact in the first three years of life ${ }^{(1)}$.

Studies on children's development often need to take into account psychosocial risk factors that

\section{REFERENCES}

1. Shore R. Rethinking the brain: new insights into early development. New York: Families and Work Institute; 1997. 2. Halpern R, Giugliani ERJ, Victora CG, Barros FC, Horta BL. Fatores de risco para suspeita de atraso no desenvolvimento neuropsicomotor aos 12 meses de vida. J Pediatr (Rio J) $2000 ; 76(6): 421-8$. cannot be eliminated, as they have already occurred, but can neutralize their negative effects through effective psychosocial support actions, in order to facilitate successful development outcomes. The process of resilience ${ }^{(6)}$ amidst adversity can be explained by the interplay between risk factors and protection mechanisms. Therefore, primary care actions in the Family Health Program need to go beyond the evaluation limited to the child's physical growth and identification of diseases, in order to reach a program of "Development Surveillance". Future studies can focus on the inter-relations of family dynamics in longitudinal designs, in order to contribute to the completion of the panorama of risk indicators for the child's development and improvement of health conditions. In addition, intervention models can be tested that take into account the neutralization of risk factors identified as adverse for global and language development.

\section{CONCLUSION}

Direct observation of the child's and family's environment and the study of their life history were essential instruments to understand the children's development profile and the families' dynamics. Despite the socioeconomic adversities experienced, the families offered adequate stimulation and the risk for development problems affected around 33\% of the sample. The child's psychosocial risk and nutritional factors deserve special attention, because they increase the chance of development problems. The findings show the relevance of analyzing both the risks and the child's and family's resources that influence the promotion of development. The implementation of a Development Surveillance Program in the Family Health Program is recommended, with continuous evaluation of children and their environmental context, followed by orientation for the prevention of development problems.

3. Rescorla L. The Language Development Survey: a screening tool for delayed language in toddlers. J Speech Hear Disord $1989 ; 54(4): 587-7$.

4. Sarue HE, Bertoni N, Diaz AG, Serrano CV. O conceito de risco e a programação dos cuidados de saúde. Manual básico de aprendizagem inicial. Montevidéu. Centro LatinoAmericano de Perinatologia e Desenvolvimento Humano CLAP, 1984 (Publicação Científica no 1007). 
5. Lewis RJ, Dlugokinski EL, Caputo LM, Griffin RB. Children at risk for emotional disorders: risk and resource dimensions. Clin Psychol Rev 1988; 8:417-40.

6. Rutter M. Psychosocial resilience and protective mechanisms. Am J Orthopsychiatry 1987; 57(3):316-31.

7. Bronfenbrenner U. A ecologia do desenvolvimento humano: experimentos naturais e planejados. Porto Alegre: Artes Médicas Sul; 1996.

8. Rutter M, Quinton D. Psychiatric disorder - ecological factors and concepts of causation. In: McGurk M, editor. Ecological factors in human development. Amsterdam: North Holland; 1977.

9. Frankenburg WK, Dodds J, Archer P, Bresnick B, Maschka $\mathrm{P}$, Edelman N, et al. Denver II: Technical Manual and Training Manual. Denver: Denver Developmental Materials; 1990.

10. Capovilla FC, Capovilla AGS. Desenvolvimento lingüístico na criança dos dois aos seis anos: tradução e estandardização do Peabody Picture Vocabulary Test de Dunn \& Dunn, e da Language Development Survey de Rescorla. Ci Cognitive 1997; 1(1):353-80.

11. Bradley RH, Caldwell BM. Home observation for measurement of the environment: a revision of the preschool scale. Am J Ment Defic 1979; 84(3):235-44.

12. Caldwell BM, Bradley RH. Administration Manual HOME Observation for Measurement of the Environment: revised edition. University of Arkansas at Little Rock. Little Rock, Arkansas; 1984.

13. Zamberlan MAT, Biasoli-Alves ZMM. Interações familiares: teoria, pesquisa e subsídios à intervenção. Londrina: Editora Universidade Estadual de Londrina (UEL); 1997.

14. Santa Maria-Mengel MR. "Vigilância do Desenvolvimento" em Programa de Saúde da Família: triagem para detecção de riscos para problemas de desenvolvimento em crianças. [doutorado]. Ribeirão Preto: Universidade de São Paulo; 2007. 15. Savoia MG. Instrumentos para avaliação de eventos vitais e de estratégias de enfrentamento (coping) em situações de estresse. In: Gorenstein C, Andrade LHSG, Zuardi AW. Escalas de Avaliação Clínica em Psiquiatria e Psicofarmacologia. São Paulo: Lemos Editorial; 2000. p. 377-86.

16. Mattar FN. Análise crítica dos estudos de estratificação sócio-econômica de ABA- ABIPEME. RAUSP 1995; 30(1):57-74.

17. Pedromônico MRM. Instrumentos de triagem e a vigilância do desenvolvimento da criança de 0 a 6 anos. In: Mendes EG, Almeida MA, Williams LCA, organizadores. Temas Educ. Esp. São Carlos: Ed. UFSCar; 2004. p. 325-30.

18. Ferreira MCT, Marturano EM. Ambiente familiar e os problemas do comportamento apresentados por crianças com baixo desempenho escolar. Psicol Refl Crít 2002; 15(1):3544.

19. Lucas A, Morley R, Cole TJ. Randomized trial of early diet in preterm babies and later intelligence quotient. BMJ 1998; $317: 1481-7$. 